\title{
A FRAGMENT OF AN OLD WELSH COMPUTUS.
}

A few months ago the fragment of Old Welsh printed below passed into the possession of the Cambridge University Library. The facsimile here given represents the exact size of the original. On the reverse are two faint diagrams, one of which Dr. M. R. James and Mr. Jenkinson identified as the Sphere of Pythagoras, for which see the latter's edition of the Hisperica Famina p. 31. Accompanying this vellum fragment is another scrap identical in size, which evidently formed part of the same volume. The two have been beheaded to the extent of about ten lines. The other fragment consists of a portion of a calendar giving the years in cycles of 19 with the dates of moveable feasts. The first year is 922 , the end of the cycle being 930 . The next cycle (931-949) reaches to the foot of the page. But on the reverse the first year is 960 , the last 987. At the year 938 a different hand has entered hic adelsta(n). It would appear then that these 23 lines of Old Welsh may have formed part of a 10th century computus. The subject-matter resembles the instructions given in Bede's Ephemeris as to the use of the regular page, which will be found in Migne vol. 90 p. 757-8, as well as in the older editions of Bede's works. But the column of letters in the calendar referred to in the Welsh text, without which the regular page cannot be worked, is only to be found in the Cologne edition of Bede's works (1537). It forms the fifth vertical column of capital letters accompanying the various months. $P$ and $Q$ against Jan. 29 and 31 are a mistake. They have come in from col.3. Old Welsh documents are unfortunately very scanty and the lack of other material renders the translation of a highly technical fragment like the present one a matter of extreme difficulty. I desire gratefully to acknowledge my indebtedness to Prof. Loth for assistance generously given, though he is not in any way to be.held responsible for my rendering. My best thanks are also due to Mr. Jenkinson for allowing me to publish the fragment and for help of varigus kinds. 


\section{Text of the fragment.}

guidaur . is mod . cephitor. did . hanaud . In ir tritid urd .i. In trited retec . retit loyr .. guorhir seraul . circhl . ir ir tri ui . aur . is did ciman . haci .. Or bissei pan diconetent ir . oith aur hinnith pa sserenn . pigurthet . loyr in pan aedbid . ad ír lóc . guac . issi .

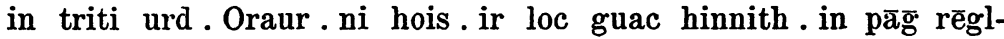
nit . abruid ir serenn . hai bu in arcimeir .o. is gur tum tarnetor ir loc guac haibid post .o. haccet . nitegid . di . a . hit niritarnher ir did hinnuith i. ir loc quac habid post .o. Ir nidibid ir loyr di . a . hit niri tarnher rann . ir bissei .. Hacet is gurth . ir serenn hai bid in eir cimeir .o. retit loyr ir did . hinnuith cen nit boi loc guac inter o. et a . in pāg regula. Is aries isid in arcimeir aries . hithou tra nos in errcimeir loc guac .i. ii kl- Iañ .. Cinnit hoys ir loc guac hinnuith In pāg rēg...post .e. issem ir .e. hinnuith issid diguedham oll in pāg rēḡ .. hac in ir gueleri .gurt trichiti nacgenei . bihit . dirterni ir loc guac hai bid in ir gueleri nitegid ad serenn árall aries ithou guar $\mathrm{kl}-\mathrm{i} \bar{a} \bar{n}$ bichet paniu petguarid . did di aries .. Sic solvendum est Salt emmiguollig hinnith ir bloidin hunnuith .ir hatbid oit guor mod in ir salt. Ceis in ir loyr ha chepi . hinn in guir . ir ni deruid hinn . hou nit bloidin salt hai bid im guarphenn circhl naunecant.

\section{Notes to the translation.}

1) According to Bede's Ephemeris the moon stays for 11 days 6 hours and two-thirds (bisse) in each constellation.

2) i. e. it is a whole day which the moon gains thereby. Or bissei perhaps means 'from, as a result of the b.'.

$\left.{ }^{3}\right)$ From $d y$-gynnyddu. The ending is perhaps to be compared with 0. W. forms in -int, cp. Strachan, Introduction p. 83.

4) For pa ...pi v. Loth, RC. XXXI, 327.

5) gurthet I take to be from gwrth + hed. In Bede 'peruolare' occurs in similar passages. Otherwise it might be $=$ gwrthyd, 'what constellation is it that the moon rejects, leaves behind? 


\section{Translation.}

it is known, it is a manner in which a difficult day is found. In the third row, i. e. in the third circuit the moon travels on the zodiac for the thrice six hours. ${ }^{1}$ ) It is a whole day with it ${ }^{2}$ ) (the moon). As regards the bisse when those eight hours increase ${ }^{3}$ ) what constellation is it to which ${ }^{4}$ ) the moon flies ${ }^{5}$ ) when it comes to it, ${ }^{6}$ ) the vacant space which is in the third row. When ${ }^{7}$ ) that vacant space is not ${ }^{8}$ ) in the regular page the constellation which was opposite 0 is not entangled. ${ }^{9}$ ) It is in excess ${ }^{10}$ ) that the vacant space which is after 0 is absorbed.11) And yet it does not pass ${ }^{12}$ ) from a in order that that day may not be absorbed, i. e. the vacant space which is after o. For the moon does not pass from a in order that a part, the bisse, be not absorbed. And yet 13) it is towards the constellation which is opposite o that the moon runs that day, since ${ }^{14}$ ) there cannot be ${ }^{15}$ ) a vacant space between 0 and $a$ in the regular page. It is aries which is opposite ... aries itself ${ }^{16}$ ) ... opposite a vacant space, i. e. 2 Cal. Jan. Although that vacant space is not in the regular page after $e$, that is, that $e$ which is last of all in the regular page and in the calendar ............... ${ }^{17}$ ) until thou absorb the vacant space which is in the calendar it does not move to another constellation. It is aries itself on Cal. Jan. until it is the fourth day of aries. Sic solvendum est. It is the saltus that releases ${ }^{18}$ ) (disturbs?) this this year. For there are eight too many in the saltus. ${ }^{19}$ ) Seek in the (table of the) moon and thou shalt find this true. For this does not fail. Is it not a saltus year which is at the end of a nineteen year cycle? ${ }^{20}$ )

6) aedbid $=a+e+d(i) b i d$, where $e$ is the infixed pronoun. This is contrary to later usage, as pan is regularly preceded by $y$, when a pronoun is infixed (Strachan p. 35). For the form triti see the instances given by Loth, RC. XXXI, 320.

7) Or aur perhaps means 'from the time that'.

s) It is interesting to find that there are two instances in this fragment of the use of oes with a definite subject, cp. Strachan p. 101.

9) abruid apparently = afrwydd.

10) = guor twf?

11) This verb occurs four times in the fragment (tarnher twice, di-rterni). Prof. Loth compares Bret. tarna, 'to sweep'; tarner, 'dish-cloth'. He informs me that the verb occurs elsewhere meanigig totg absorbj/dgy Ad,'. 
12) I can offer no satisfactory explanation of this form which occurs once again. The absolute form egid is out of the question. Prof. Loth writes: 'à propos de tegid, je me souviens d'avoir entendu employer couramment à Carnarvon: tynghyd dans le sens de 'fuir', par exemple pour un bateau s'enfuyant devant la tempête. $g$ intervocalique est souvent pour $n g$, rarement, il est vrai, pour nc.'

13) = ac cyd?

better than cyny.

14) cen nit = 'since not' for can nyd? This seems to suit the sense

15) $b o i=b u y$ ? written ithou.

16) hithou = hitheu fem. referring to serenn? A few lines later it is design'?

17) gurt trichiti, cp. gwrthrychu, gwrthddrychu, 'to place in view,

18) Apparently from ymollwng. It is natural to think of 0 . Irish relative forms such as imme-rádi. Prof. Loth also suggested this explanation, but he holds that $-i$ - may represent an ordinary infixed pronoun, the verb having the usual reflexive force.

19) I do not understand the purport of this.

20) naunecant evidently renders Lat. decemnouennalis. Cp. Bret. naondec. But what is the latter part? W. cant means 'a rim, hoop, periphery' etc.

Cambridge.

E. C. Quigain. 